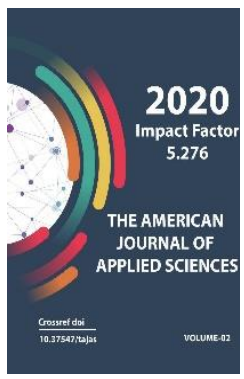

\title{
The Condition Of General Development Of The Mineral Resource Base In Uzbekistan
}

\author{
Umirzoqov Azamat Abdurashidovich \\ PhD Scholar Of The Department Of Mining, Tashkent State Technical University Named After \\ Islam Karimov, Republic Of Uzbekistan, Tashkent
}

\footnotetext{
Copyright: Original content from this work may be used under the terms of the creative commons attributes 4.0 licence.
}

\section{ABSTRACT}

The development of methods and means to improve the efficiency of the mining facility is aimed at improving the efficiency of the use of raw materials concentrated in deposits of natural and man-made origin. This increase in efficiency is manifested through maximizing the content of commercial ore shipped for processing, creating prerequisites for increasing the shipment of commercial ore and increasing the productivity of the processing plant. Maximization of the content in commercial ore is based on the developed scheme of cyclical increase in the efficiency of resource potential use for the entire period of field development, supplemented by an improved method of current mining planning based on anisotropy of contents and dynamic conditions.

\section{KEYWORDS}

Quarry, deposit, mining operations, rock, formation, drilling equipment, rock mass, small-scale gold mining, explosive, gold mining.

\section{INTRODUCTION}

The creation of prerequisites for increasing the shipment of commercial ore is based on the redistribution of dump trucks between overburden and ore cargo flows, which is possible from reducing the distance of overburden transportation as a result of the implementation of the "Fill - release - fill" cycle when working out ore warehouses in the external space.

The creation of prerequisites for improving the productivity of the processing plant is based on reducing mill downtime due to oversized ingress. For this purpose, segregation is used, as a result of which the dumps are divided by 
height into technogenic and technological zones with different granulometric composition of rocks. This division of dumps into zones is used for selective development of dumps with purposeful formation of cargo flows depending on the size of the pieces in the shipped ore and equipment at the receiving node of the processing plant.

\section{MATERIAL AND METHODS}

The development of a scheme for the cyclical use of the resource potential of deposits is aimed at achieving the target function defined in accordance with the priorities in the development of the field. At the same time, this scheme provides a solution to operational tasks for the production of finished products in conditions of naturally decreasing content and increasing prices of mineral raw materials.

The results of research on the impact of technical and economic indicators of mining operations on the boundaries of the quarry and the resource potential of the field, allowed us to conclude that the period of activity of the mining complex is divided into two characteristic stages.

At the same time, during the 1st stage, the field development is carried out according to the scheme with profit maximization, and the 2ndaccording to the scheme with resource potential maximization. The appearance of these stages is determined by the economic conditions for the development of mining operations, and the boundary between them for the Muruntau field is the depth of the quarry at $600 \mathrm{~m}$. Therefore, the development of the Muruntau field is approaching the moment of adjustment of the external economic environment with a reduction in fees for mineral resources from $30 \%$ to $10-15 \%$, which, of course, will have a positive impact on the efficiency of using its resource potential.

\section{RESULTS}

Regardless of the period of development of the quarry, the management of the mineral resource base of the mining and processing complex is based on:

- Division of the rock mass by grades with the release of conditioned ore at hierarchical levels of the system " Depositquarry-natural and technological zone excavation block-face-portion-piece»;

- A consistent reduction in the conditions for commercial ore as the quarry develops in time and space, with the definition of conditions for reducing the onboard content;

- Separate storage of various grades of rock mass with the release of commercial ore, off-balance sheet ore and rock;

- Determining the conditions for involving off-balance sheet ore in processing.

The separation of rock mass by grades with the release of conditioned ore at the "Deposit quarry" levels occurs in the process of building a mathematical model of the Deposit during the development of the quarry project. At the same time, the basic onboard content is allocated. In particular, for the Muruntau Deposit, this content is $2 \mathrm{~g} / \mathrm{t}$. At the same time, the boundaries of the ore mass division by grades are determined. When designing the Muruntau quarry, the contents of 2.0-1.5 g/t and 1.5-1.0 g/t were taken beyond the boundaries of off-balance ore, and the conditions for involving off-balance ore in processing were determined. Basically, these reserves are extracted during the 1st stage of the quarry operation.

In the future, the performed research proved the feasibility of allocating another grade of off-balance ore with the boundaries of 1.0-0.5 g I t to a separate cargo flow. In addition, it is considered appropriate to divide the overburden cargo flow into the external overburden cargo flow $(\mathrm{SSR}=0)$ and the 
internal overburden cargo flow $(\mathrm{SB}=0.3 \mathrm{~g} / \mathrm{t}$ with $\mathrm{SSR}=0.65 \mathrm{~g} / \mathrm{t}$ ). Basically, these reserves are extracted during the 2nd stage of the quarry operation.

In General, the involvement of raw materials in processing, regardless of the period of operation of the quarry, occurs cyclically, when the raw material waste of the previous stage becomes the raw material of the next stage (Fig. P. 4.3). In the Muruntau quarry, the 3rd stage of development of raw materials is under implementation, and preparations are underway for the 4th stage.

When moving to the 3 rd stage with an onboard content of $S B=1.0 \mathrm{~g} / \mathrm{t}$, the waste of the previous stage with a content of 1.0-1.5 g/t is involved in processing, and the rock mass with a content of less than $1.0 \mathrm{~g} / \mathrm{t}$ becomes mining waste. In the transition to the 4th stage down side to $\mathrm{SB}=0.5 \mathrm{~g} / \mathrm{t}$ of waste of the previous phase with a content of $0.5 \div 1.0 \mathrm{~g} / \mathrm{t}$ be the raw material and are involved in processing a rock mass containing less than $0.5 \mathrm{~g} / \mathrm{t}$ becomes a waste of production.

The division of rock mass by grades at the "quarry - natural-technological zone" levels occurs at annual and monthly, "naturaltechnological zone - mining block" - monthly and daily, and "mining block - face" - daily and shift planning of mining operations.

The division of the rock mass by grade begins with the allocation of the ore - rock boundary on the grade plans of the excavation blocks and the determination of the adjacent rock band containing a certain amount of gold. Naturally, due to the uneven structure of deposits and the distribution of content in the array in this band, there will be areas with abnormal content, surrounded by almost empty rock. In addition, these areas will contain areas with abnormally low content with reserves of up to several hundred tons of rock mass.
The consequence of this structure of deposits is that in each grade of ore mass there is some part of the material that does not correspond to the boundaries of the grade. For example, in an ore mass with grade boundaries of 1.0-0.5 $\mathrm{g} / \mathrm{t}$, there is $30-40 \%$ of the material with a content of up to $0.5 \mathrm{~g} / \mathrm{t}$ and more than $1.0 \mathrm{~g} / \mathrm{t}$. Therefore, it is advisable to select the material we are interested in from the total mass, which will allow us to get an additional 80-100 million tons of commercial ore before the end of mining.

\section{DISCUSSIONS}

Management scheme mineral resources base of mining and processing complex provides for the addition of period of operation of the quarry under the scheme with the maximization of profit by the period of operation by maximizing the use of resource potential of the Deposit. At the same time, cyclical involvement in the processing of raw materials with a consistently decreasing content and the use of additional production cycles to isolate the enriched part of the mineral from unpromising waste is envisaged. Today, such wastes are overburden rocks with an average content of $0.30-0.35 \mathrm{~g} / \mathrm{t}$.

The adopted strategy of using the resource potential with a consistent reduction in the content of commercial ore in stages is the basis for the transition to dynamic conditions in the development of deposits with an economically established boundary between commercial ore and current production waste.

Combined management of raw materials of natural and man-made origin is based on the developed methods of continuous design and planning, which made it possible to reduce and maintain the volume of mining operations at the level of 35,500 thousand $\mathrm{m} 3$ per year for 8 years, while simultaneously increasing the production of gold at reduced production costs. Finished with ore stage III quarry and 
mining his fourth line determines the necessity of increasing the output of the mining complex that is connected, on the one hand, with objectively lower the quality and quantity of ore in the bowels, and, on the other hand, the increased capacity of the processing facilities. Therefore, since 2009 a single raw material base combined deposits of Muruntau and Mutenbei and inventories in Zone 4. The productivity increases, which commissioned 8 excavators and the dump truck 21. Additionally, the point of the TTC complex is close to the zone of intensive work in the external warehouse in Zone 4.

However, the reduction in ore production in the Muruntau quarry during the mining preparatory work and the opening of the main reserves of stage 4 requires measures to compensate for this decrease from other sources. Moreover, the volumes of not only reduced production, but also increased productivity of the plant should be compensated. At the same time, the existing reserve deposits (Mutenbai, Besapantau, Boylik, Triada, Kosmanachi) cannot provide such compensation either in time or in quantity. The only real source that can ensure the fulfillment of this task is the warehouse stocks of the Muruntau quarry and, in particular, the largest warehouse Zone 4. In this regard, since 2008, the shipment of ore from external warehouses has increased sharply.

In addition, the warehouse's ore allowed implementing a strategy for regulating the intensity of mining operations in natural and technological zones in the quarry. For this purpose, after working out the natural and technological zone to the intermediate circuit, ore was extracted from an external warehouse for the duration of overburden operations. After the overburden was completed, the ore zone was again intensively lowered to the next intermediate contour.
After 2008, the nature of ore shipment from an external warehouse changed, which is a consequence of a change in the strategy for managing the reserves of the field and combining the raw materials of the hydrometallurgical plant and the heap leaching shop. This made it possible to involve 30,000 thousand tons of ore of the 1.50-2.0 g/t grade in mining, firstly earlier than planned; secondly, in a larger volume; and thirdly, to process this ore at the GMZ and not at the KV, which increased extraction. From the point of view of inventory management and planning, this solution is the equivalent of building, commissioning and testing for 3 years.

At the same time, there are all the distinctive features of the field development by an independent quarry:

1. the construction Period is the opening of the southern part of warehouse $3 \mathrm{E}$ in November - December 2008, and the opening of the Northern part of warehouse 3E in February-March 2009.

2. Reaching the design capacity and development of the 1st stage of the quarryApril 2009-January 2010, ore shipment of 6195 thousand tons ( 516 thousand tons per month), Stripping operations - 2040 thousand m3 (200 thousand m3 per month).

3. Development of the 2nd stage of the quarry-February 2010-December 2010, shipment of ore 21000 thousand tons ( 1750 thousand tons per month), overburden 12000 thousand m3 (1000 thousand m3 per month).

4. Damping of mining operations - January February 2011, completion of 500 thousand tons of ore.

At the same time, the average gold content in the ore shipped from the external warehouse $3 \mathrm{E}$ will be $1.56 \mathrm{~g} / \mathrm{t}$.

However, the reserves of ore of this quality in external warehouses will be exhausted in the 
1st quarter of 2011. As a result, to maintain gold output at the level of 2009-2010, it will be necessary by this time either to reach the main ore reserves of stage IV in the quarry in order to increase the quantity and quality of ore, or to involve a new Deposit with higher-quality ore reserves in development. In the latter case, when outlining reserves for the first stage of development, it is advisable to use the $1.50 \mathrm{~g} / \mathrm{t}$ content as the base on-Board content, since a significant amount of ore of the 1.0-1.50 g/t grade (average $1.09 \mathrm{~g} / \mathrm{t}$ ) will still remain in external warehouses.

For the system "quarry plant" set the border cost-effective processing of mineral raw materials of man-made structures depending on the metal content of the ore and the world realized gold price.

So, when the world realized gold price equal to $1441,25 \$ / 0 z$ cost-effective ore processing at HMP-2 containing more than $0.31 \mathrm{~g} / \mathrm{t}$, at a price $1200,0 \$ / 0 z 0.39 \mathrm{~g} / \mathrm{t}$, at a price $1600,0 \$ / 0 z 0.28$ $\mathrm{g} / \mathrm{t}$.

The problem of increasing the efficiency of management of the mineral resource base of mining and processing complexes in the development of deposits of natural and manmade origin is solved:

-The structure of formation and movement of mineral resource flows in the "quarry-plant" system is justified. Grades of balance and offbalance ore and overburden are allocated to separate cargo flows. Control of structure formation and traffic intensity in the system "quarry plant" in time to compensate for the shortage of mined ore in a career of off-balance ore from man-made structures (external warehouse) stockpiled at the open pit of the previous stage of development.

\section{CONCLUSIONS}

Ore from the warehouse allows you to implement a strategy for regulating the intensity of mining operations in natural and technological zones in the quarry. For this purpose, after the development of the natural and technological zone to the intermediate contour, the off-balance ore of technogenic formations is extracted and shipped to the plant from an external warehouse for the duration of overburden operations. After overburden is completed, the ore zone is again intensively lowered to the next intermediate contour, which allows managing raw materials;

- It is established that the consistent depletion of reserves of deposits necessitates a" step-by-step " revision of design conditions. At each "stage" of the revision, the planned long-term conditions and periods of work with short-term conditions aimed at forming the ore flow in real time are sequentially allocated;

- Developed method of operational control of the resource base through the application of dynamic conditions, involving the use of warehouses offbalance ore technogenic formations as a buffer element in the ore stream career, which is used if necessary to regulate the quality of the ore stream.

\section{REFERENCES}

1. Khayitov, O. G. Evolution Of Petroleum Stratum Efficiency By - Multi-Factor Regression Analysis//The American Journal of Engineering and Technology. https://usajournalshub.com/index.php/tajet /article/view/814.

2. Nasirov U.F., Ochilov Sh.A., UmirzoqovA.A. Analysis of Development of Low-Power and Man-Made Gold Deposits// International Journal of Academic and Applied Research 
(IJAAR)ISSN: 2643-9603 Vol. 4, Issue 4, April - 2020, Pages: 71-74.

3. Umirzoqov A.A., Jurayev S.J., KaramanovA.N. Economic and mathematical modeling of rational development of small-scale and man-made gold deposits// International Journal of Academic and Applied Research (IJAAR), Vol. 4, Issue 4, April - 2020, Pages: 75-77.

4. HayitovO.G.,UmirzoqovA.A.,Iskandarov J.R., Suvanov F.R. Prospects for the industrial use of coal in the world and its process of reproducing//Novateur Publication's JOURNALNX- A Multidisciplinary Peer Reviewed Journal, Volume 6, Issue 5, may-2020, Pages:240-247.

5. KazakovA.N., UmirzoqovA.A., RadjabovSh.K., MiltiqovZ.D. Assessment of the Stress-Strain State of a Mountain Range// International Journal of Academic and Applied Research (IJAAR), Vol. 4 - Issue 6 (June - 2020),Pages:17-21.

6. Nasirov U.F., Ochilov Sh.A., Umirzoqov A.A. Theoretical Calculation of the Optimal Distance between Parallel-close Charges in the Explosion of High Ledges// Journal of Advanced Research in Dynamical and Control Systems - JARDCS, Vol. 12,07special issue, 2020, Pages: 2251-2257. https://www.jardcs.org/abstract.php?id=57 78

7. Umirzoqov A.A.,Karamanov A. N., Radjabov Sh. K. Study of the feasibility of using intermediate buffer temporary warehouses inside the working area of the Muruntau quarry/l International Journal of Engineering and Information Systems (IJEAIS), Vol. 4, Issue 8, August - 2020, Pages 140-142.

http://www.ijeais.org/ijeais/index.php/ijeais $-4-8-2020 /$

8. Khayitov O.G', Umirzoqov A.A.,Bekmuratov A.O. Small Torch Progress In Prospects Gold Mining In Improving Countries// The American Journal of Interdisciplinary Innovations and Research, 2(09), 65-72.
https://doi.org/10.37547/tajiir/Volume02Issu eog-11.

9. Mirzarakhimov M.S., Iskandarov J.R.,Umirzoqov A.A.,Amanov T.S. Technology Of Modified Sodium-Aluminum Catalysts For Nitrogen Gas Purification Systems// The American Journal of Applied Sciences, 2(09),154-163. https://doi.org/10.37547/tajas/Volumeo2lssu eog-24

10. Khakimov K.D., Eshonqulov U.K., Amanov T.S., Umirzoqov A.A. Complex Processing Of Lead-Containing Technogenic Waste From Mining And Metallurgical Industries In The Urals/l The American Journal of Engineering and Technology, 2(09), 102-108. https://doi.org/10.37547/tajet/Volume02Issu eog-19

11. Snitka N.P., Nasirov U.F., Mislibaev I.T., Nutfulloyev G.T. Resource-saving technologies for drilling and blasting operations at quarries / Under the general editorship of Yu.D. Norov. - Tashkent: Fan, 2017. - $256 \mathrm{p}$.

12. Zairov Sh.Sh., Belin V.A., Gorbonos M.G., Nutfulloyev G.S., Tukhtashev A.B. Blasting work // Tutorial. - Bukhoro, publishing house "Bukhoro", 2017. - 136 p.

13. Nasirov U.F., Ochilov Sh.A., Ravshanova M.H. Theoretical studies of the mechanism of crushing rock rocks with the explosion of high ledges // Izvestiya Vysshikh Uchebnykh Zavedenii. Mountain magazine. Ekaterinburg: ed. UGSU, 2017. - № 3. - P. 3844.

14. Mislibaev IT, Soliev B.Z. A complex study of the physico-chemical properties of an array of strong sandy rocks // Gorny Vestnik of Uzbekistan. - Navoi, 2017. - № 2. - P. 23-25.

15. Ochilov Sh.A., Nasirov U.F., Toshniyozov L.G. The oretical study of the fracture mechanism of less fissured rocks. Austrian Journal of Technical and Natural Sciences. Austria, 2017. - №1-2. R. 98-101. 